Italian Literature and Thought Series 
The Italian Literature and Thought Series makes available in English representative works of Italian culture. Although the series focuses on the modern and contemporary periods, it does not neglect the bumanistic roots of Italian thought. The series includes monographs, anthologies, and critically updated republications of canonical works, as well as works of general interest.

ADVISORY BOARD

Peter Carravetta

City University of New York

Umberto Eco

University of Bologna

Giuseppe Mazzotta

Yale University

Lucia Re

University of California, Los Angeles

Massimo Riva

Brown University

Paolo Valesio

Columbia University

Rebecca West

University of Chicago 


\section{Italian Tales}

An Anthology of Contemporary Italian Fiction

Edited by Massimo Riva 
Copyright $(2004$ by Yale University. All rights reserved.

This book may not be reproduced, in whole or in part, including illustrations, in any form (beyond that copying permitted by Sections 107 and 108 of the

U.S. Copyright Law and except by reviewers for the public press), without written permission from the publishers.

Designed by Rebecca Gibb. Set in Janson type by Integrated Publishing Solutions. Printed in the United States of America.

Library of Congress Cataloging-in-Publication Data

Italian tales : an anthology of contemporary Italian fiction / edited by Massimo Riva.

p. cm.-(Italian literature and thought series)

Includes bibligraphical references.

ISBN 0-300-09530-9

I. Short stories, Italian-Translations into English. 2. Italian fiction-2 Ist century-Translations into English. I. Riva, Massimo. II. Series.

$$
\begin{gathered}
\mathrm{PQ}_{42}{ }_{57} \cdot \mathrm{E}_{5} \mathrm{I}_{4} \quad 2004 \\
853^{\prime} .0108092-\mathrm{dc} 22 \\
200404228 \mathrm{I}
\end{gathered}
$$

A catalogue record for this book is available from the British Library. The paper in this book meets the guidelines for permanence and durability of the Committee on Production Guidelines for Book Longevity of the Council on Library Resources. 